\title{
Organic aerosol evolution and transport observed at Mt. Cimone (2165 m a.s.l.), Italy, during the PEGASOS campaign
}

\author{
M. Rinaldi ${ }^{1}$, S. Gilardoni ${ }^{1}$, M. Paglione ${ }^{1}$, S. Sandrini ${ }^{1}$, S. Fuzzi ${ }^{1}$, P. Massoli ${ }^{2}$, P. Bonasoni ${ }^{1}$, P. Cristofanelli ${ }^{1}$, \\ A. Marinoni ${ }^{1}$, V. Poluzzi ${ }^{3}$, and S. Decesari ${ }^{1}$ \\ ${ }^{1}$ National Research Council, Institute of Atmospheric Sciences and Climate, Bologna, Italy \\ ${ }^{2}$ Aerodyne Research Inc., Billerica, MA, USA \\ ${ }^{3}$ Centro Tematico Regionale Aree Urbane, Arpa Emilia-Romagna, Bologna, Italy \\ Correspondence to: M. Rinaldi (m.rinaldi@isac.cnr.it)
}

Received: 30 March 2015 - Published in Atmos. Chem. Phys. Discuss.: 22 May 2015

Revised: 25 September 2015 - Accepted: 1 October 2015 - Published: 12 October 2015

\begin{abstract}
High-resolution aerosol mass spectrometer measurements were performed, for the first time, at the Mt. Cimone Global Atmosphere Watch (GAW) station between June and July 2012, within the EU project PEGASOS and the ARPA-Emilia-Romagna project SUPERSITO. Submicron aerosol was dominated by organics $(63 \%)$, with sulfate, ammonium and nitrate contributing the remaining 20 , 9 and $7 \%$, respectively. Organic aerosol (OA) was in general highly oxygenated, consistent with the remote character of the site; our observations suggest that oxidation and secondary organic aerosol (SOA) formation processes occurred during aerosol transport to high altitudes. All of the aerosol component concentrations as well as the OA elemental ratios showed a clear daily trend, driven by the evolution of the planetary boundary layer (PBL) and by the mountain wind regime. Higher loadings and lower OA oxidation levels were observed during the day, when the site was within the PBL, and therefore affected by relatively fresh aerosol transported from lower altitudes. Conversely, lower loadings and higher OA oxidation levels were observed at night, when the top of Mt. Cimone resided in the free troposphere although affected by the transport of residual layers on several days of the campaign. Analysis of the elemental ratios in a Van Krevelen space shows that OA oxidation follows a slope comprised between -0.5 and -1 , consistent with addition of carboxylic groups, with or without fragmentation of the parent molecules. The increase of carboxylic groups during OA ageing is confirmed by the increased contribution of organic fragments containing more than one oxygen atom in the free troposphere night-time mass spectra. Finally, positive matrix
\end{abstract}

factorization was able to deconvolve the contributions of relatively fresh $\mathrm{OA}(\mathrm{OOAa})$ originating from the PBL, more aged $\mathrm{OA}(\mathrm{OOAb})$ present at high altitudes during periods of atmospheric stagnation, and very aged aerosols (OOAc) transported over long distances in the free troposphere.

\section{Introduction}

Atmospheric aerosols have been intensively studied in the last decades because of their effects on climate, air quality and ecosystems. In many environments, organic aerosol (OA) constitutes a dominant fraction of submicron particles mass (Zhang et al., 2007; Jimenez et al., 2009). OA is made of thousands of individual compounds that can either be emitted directly into the atmosphere (i.e. primary OA or POA) or formed through chemical and physical processes (i.e. secondary OA or SOA). Given the extremely wide range of properties (polarity, vapour pressure, etc.) and number of compounds, typically only $10-20 \%$ of the OA mass can be speciated at the molecular level (Seinfeld and Pankow, 2003).

$\mathrm{OA}$ is a dynamic component, experiencing both atmospheric oxidation and reversible partitioning. This processing (usually referred to as ageing) is generally not completely understood and not well represented in models (Heald et al., 2010). In the last decade, online instruments like the Aerodyne Research Inc. aerosol mass spectrometer (AMS) (Jayne et al., 2000; Canagaratna et al., 2007) have provided new insights into OA chemical composition and simplified ways of characterizing atmospheric OA ageing. $\mathrm{Ng}$ et al. (2010) 
showed that OA composition tends to become less variable with photochemical ageing, regardless of its source, with the most oxidized spectra resembling that of fulvic acid. Heald et al. (2010) applied the Van Krevelen diagram (H:C vs. O : C space) to the elemental composition of ambient and laboratory OA, observing that bulk OA elemental ratios follow a line characterized by a slope of -1 . This implies that OA ageing involves, on average, the addition of carboxylic acids or equal amounts of hydroxyl and carbonyl functionalities. By contrast, based on a worldwide data set, $\mathrm{Ng}$ et al. (2011) observed a slope of $\sim-0.5$ for the oxidation of SOA which is characteristic of the addition of alcohol, carbonyl and carboxyl functionalities during the ageing process, or of the addition of carboxylic groups accompanied by a $\mathrm{C}-\mathrm{C}$ bond cleavage (molecular fragmentation). Recently, Holzinger et al. (2013) showed that fragmentation gains importance over functionalization as the photochemical age of OA increases, as originally proposed by Kroll et al. (2009). Finally, both ambient observations (Jimenez et al., 2009; Morgan et al., 2010) and laboratory studies (Massoli et al., 2010; Lambe et al., 2011) have pointed out that atmospheric ageing lowers OA volatility and enhances their hygroscopicity, evidencing the importance of atmospheric processing in determining the OA climate-relevant properties.

In this study, we investigate the atmospheric processing of OA over the Po Valley basin, taking advantage of the unique observatory of Mt. Cimone, part of the Global Atmosphere Watch (GAW) network by the World Meteorological Organization (WMO), a suitable location to study tropospheric background conditions. As many other mountain sites are close to anthropogenically impacted areas, Mt. Cimone provides the opportunity to investigate transport and chemical processing of polluted air masses lifted by convection or by pressure gradients on the mountain slopes (valley breezes) (Marinoni et al., 2008; Gilardoni et al., 2009).

The first AMS measurements performed at high-altitude mountain stations were reported by Hock et al. (2008) and by Lanz et al. (2008). In particular, the latter study highlighted lower concentrations and higher oxygen content in aerosols collected at the Hohenpeissenberg (Germany) and Jungfraujoch (Switzerland) stations compared to measurements performed simultaneously at low-altitude sites. Sun et al. (2009) and Freney et al. (2011) confirmed these findings with measurements performed at Whistler Mountain (Canada), and Puy de Dome (France), respectively, and provided useful insights of seasonal effects and air mass origin on the physicochemical properties of regional aerosol particles measured at elevated sites.

The Mt. Cimone GAW/WMO station is a high-altitude research site located in the north Italian Apennines, facing the heavily populated and industrialized Po Valley region. In this study, we present and discuss online submicron aerosol chemical composition data collected at Mt. Cimone by a high-resolution time-of-flight aerosol mass spectrometer, HR-ToF-AMS (DeCarlo et al., 2006), during sum- mer 2012, within the EU project PEGASOS and the Agenzia Regionale per la Prevenzione e l'Ambiente (ARPA) Emilia-Romagna SUPERSITO project. The measurements were used to characterize the summer background aerosol transported into the Po Valley basin area, the vertical transport of anthropogenic aerosol from the lower troposphere (typical of summer circulation) and the regional-scale oxidation of OA. Prior to this study, aerosol chemical composition data for Mt. Cimone station were reported by Putaud et al. (2004), Marenco et al. (2006) and Carbone et al. (2010, 2014) using offline aerosol characterization techniques (i.e. filter samples analysed by ion chromatography and organic carbon analysis). All these papers evidenced the importance of the OA fraction in submicron aerosol at the site, both in summer and winter. However, this is the first time that online characterization of atmospheric aerosol, particularly of OA, was performed with high resolution on a mountain site at the centre of the Mediterranean climate hotspot region.

\section{Methods}

\subsection{Sampling site}

Mt. Cimone is the highest peak of the north Italian Apennines. The top of Mt. Cimone $\left(44^{\circ} 11^{\prime} \mathrm{N}, 10^{\circ} 42^{\prime} \mathrm{E}\right.$; $2165 \mathrm{~m}$ a.s.l.) hosts the Italian Climate Observatory "O. Vittori" that is part of the GAW program of the WMO. The station is situated at the southern border of the Po Valley, which is a highly populated and industrialized area, also characterized by intense agricultural activities. Anticyclonic conditions often favour a reduced ventilation within the basin, promoting the build-up of lower troposphere aerosols and pollutants.

Measurements of atmospheric components carried out at this site are generally considered representative for the south European free troposphere (Bonasoni et al., 2000; Fischer et al., 2003). Nevertheless, due to enhanced vertical mixing occurring during summer months, a daytime influence at Mt. Cimone from the planetary boundary layer (PBL) has been documented (Fischer et al., 2003; Cristofanelli et al., 2007). For these reasons, this measurement site can represent a suitable location to investigate the influence of both local and long-range transport of polluted air masses on the free troposphere composition (Marinoni et al., 2008).

\subsection{Online aerosol chemical characterization}

The mass loading and the size-resolved chemical composition of submicron aerosol particles was characterized online by the Aerodyne HR-ToF-AMS. The HR-ToF-AMS provides measurements of the non-refractory sulfate, nitrate, ammonium, chloride, and organic mass in submicron particles $\left(\mathrm{NR}-\mathrm{PM}_{1}\right)$. During the whole campaign, the HRToF-AMS was operating by alternating between "V" and "W" ion path modes every $5 \mathrm{~min}$. The $\mathrm{V}$ mode is character- 
ized by higher sensitivity and lower mass resolution, while the $\mathrm{W}$ mode provides higher mass resolution, but lower sensitivity. The concentrations reported here correspond to the data collected in $\mathrm{V}$ mode. In $\mathrm{V}$ mode, the instrument also acquires information about size distribution of particles, or particle time-of-flight, pToF (Jimenez et al., 2003). The AMS has an effective $50 \%$ cut-off for particle sizes below $80 \mathrm{~nm}$ and above $600 \mathrm{~nm}$ in vacuum aerodynamic diameter $\left(d_{\mathrm{va}}\right)$, as determined by the transmission characteristics of the standard aerodynamic lens (Liu et al., 2007). Changes in ambient pressure may lead to changes in lens transmission efficiencies (Liu et al., 2007; Bahreini et al., 2008), but such effects are not expected to be significant under the pressure conditions typical of Mt. Cimone (Liu et al., 2007; Sun et al., 2009). However, the particle velocity calibration was adjusted to the altitude (and pressure) conditions of the Mt. Cimone site before starting the measurements. Ionization efficiency (IE) calibrations were performed before and after the campaign, and once per week during the campaign. Filter blank acquisitions during the campaign were performed at least a couple of times per day to evaluate the background and correct the gas-phase contribution. All data were analysed using standard ToF-AMS analysis software SQUIRREL v1.51 and PIKA v1.10 (D. Sueper, available at: http://cires.colorado.edu/jimenez-group/ ToFAMSResources/ToFSoftware/index.html) within Igor Pro 6.2.1 (WaveMetrics, Lake Oswego, OR). Positive matrix factorization (PMF) analyses of the HR-ToF-AMS data were performed using the PMF2.exe algorithm (v.4.2) in robust mode (Paatero and Tapper, 1994). The PMF inputs (mass spectral and error matrices of the OA component) were prepared according to Zhang et al. (2011). The PMF solutions were then evaluated with an Igor Pro-based PMF evaluation tool (PET, v. 2.04) following the method described in Ulbrich et al. (2009) and Zhang et al. (2011). The HR-ToF-AMS collection efficiency (CE) was calculated according to Middlebrook et al. (2012) and evaluated against parallel offline measurements (Fig. S1 in the Supplement). The average CE for the campaign was $0.52 \pm 0.06$. The propagated, overall uncertainty for the total AMS mass concentration is $20-35 \%(2 \sigma)$ according to Middlebrook et al. (2012). The aerosol was sampled via a total suspended particle (TSP) aerosol inlet, which is built according to the EUSAAR/ACTRIS protocol to improve the collection performances at high altitude. The aerosol was dried to about $40 \%$ by means of a Nafion drier before sampling with the HR-ToF-AMS.

\subsection{Additional measurements}

Ancillary measurements at Mt. Cimone conducted during the campaign included meteorological parameters and other trace gases $\left(\mathrm{CO}, \mathrm{O}_{3}, \mathrm{NO}_{x}\right)$. Trace gas measurements were carried out by using a common sampling system designed for reactive gas sampling, characterized by an intake line located
$2 \mathrm{~m}$ above the roof and $7 \mathrm{~m}$ above the ground and consisting of a glass tube through which the sampled air is passed at a high flow rate (larger than $20 \mathrm{~L} \mathrm{~s}^{-1}$ ). Sample air was supplied to the various analysers via a Teflon manifold pipe (about $1 \mathrm{~m}$ long) connected to the glass tube. A particle filter (changed regularly every 15-30 days) prevented dust, raindrops and other unwanted material from entering the inlet.

Surface ozone $\left(\mathrm{O}_{3}\right)$ was continuously measured $(1 \mathrm{~min}$ time resolution) by a UV-absorption analyser Dasibi 1108 W/GEN (Cristofanelli et al., 2015). Carbon dioxide (CO) was measured by a non-dispersive infrared (NDIR) analyser Thermo Tei 49C. Following Henne et al. (2008), the system and sampling procedures have been modified to carry out observations in remote conditions usually characterized by low mixing ratios. During the PEGASOS campaign, $\mathrm{NO}_{x}$ measurements were carried out by a chemioluminescence analyser (Thermo 42C). This instrument is equipped with a molybdenum converter to determine $\mathrm{NO}_{x}$, which according to Steinbacher et al. (2007), can overestimate the $\mathrm{NO}_{2}$ up to $\sim 50 \%$ due to the interference of oxidized nitrogen compounds $\left(\mathrm{NO}_{y}\right)$ such as peroxyacetyl nitrate and nitric acid.

The measurement of the aerosol absorption coefficient was obtained by a Multi-Angle Absorption Photometer (MAAP 5012, Thermo Electron Corporation), which measures the transmission and the back scattering of a light beam incident on a fiber filter where aerosol particles are deposited by the sampling flow. The equivalent black carbon (eqBC) concentration has been obtained by using a mass absorption efficiency of $6.5 \mathrm{~m}^{2} \mathrm{~g}^{-1}$, as recommended by Petzold et al. (2002).

$\mathrm{PM}_{1}$ offline aerosol samples were collected on quartz filters as described by Carbone et al. (2014) with a $12 \mathrm{~h}$ sampling resolution. Chemical analysis of main inorganic species was performed via ion chromatography and carbon elemental analysis (Carbone et al., 2014).

\section{Results}

\subsection{Online aerosol chemical characterization at Mt. Cimone}

Figure 1 shows the time trend of the major non-refractory components of submicron aerosol $\left(\mathrm{NR}-\mathrm{PM}_{1}\right)$ measured at Mt. Cimone during the campaign, together with the timedependent relative mass contribution of the same aerosol components. NR-PM 1 was clearly dominated by OA through the whole campaign: OA average atmospheric concentration and standard deviation were $2.8 \pm 2.4 \mu \mathrm{g} \mathrm{m}^{-3}$, for an average mass contribution of $63 \%$. Sulfate was the second most abundant species with a concentration of $0.92 \pm 0.60 \mu \mathrm{g} \mathrm{m}^{-3}$ (20\%), followed by ammonium $\left(0.41 \pm 0.33 \mu \mathrm{g} \mathrm{m}^{-3}, 9 \%\right)$ and nitrate $\left(0.33 \pm 0.46 \mu \mathrm{g} \mathrm{m}^{-3}, 7 \%\right)$. Chlorine was usually below the detection limit ( $80 \%$ of the data points) and contributed less than $1 \%$ to the NR-PM (and was therefore 

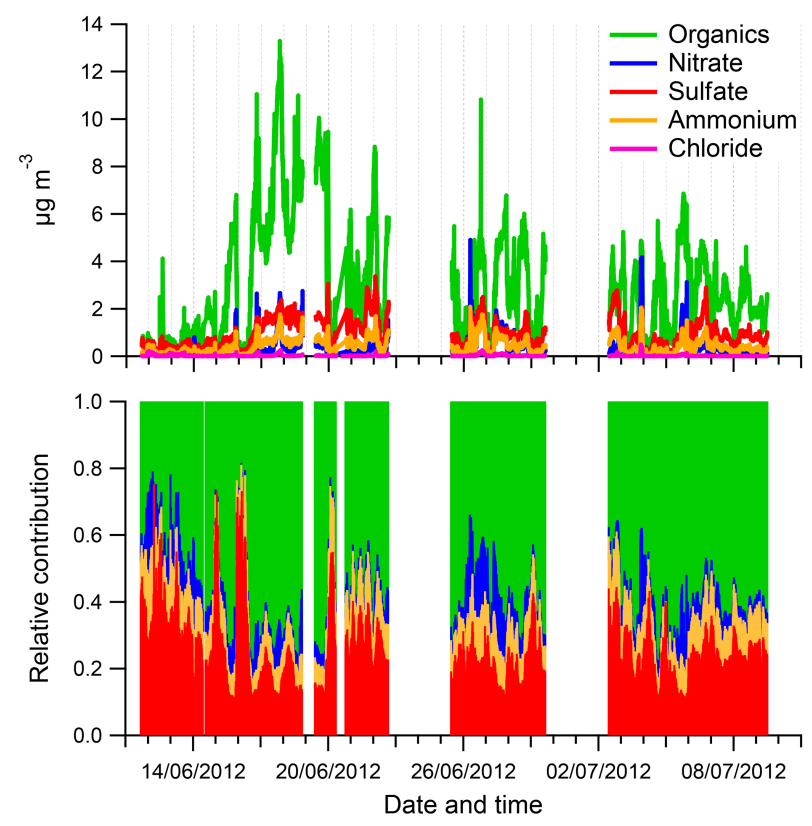

Figure 1. Time series and relative contribution of the main NR-PM components. Time is local (UTC $+2 \mathrm{~h}$ ).

excluded from Fig. 1b). For comparison, submicrometric aerosol chemical characterization measurements performed in spring and summer at high (Jungfraujoch) and rural (Hohenpeissenberg) sites in Europe (Hock et al., 2008; Lanz et al., 2010) report organics ranging from 43 to $50 \%$, sulfate ranging from 19 to $26 \%$, ammonium contributing between 13 and $11 \%$ and nitrate ranging from 18 to $19 \%$ (see Table 1 for a summary of AMS measurements performed at background measurements sites).

The measured ammonium concentrations were in equivalent concentrations to the sum of sulfate, nitrate and chloride, with a slope of 0.99 and a linear correlation coefficient $(R)$ of 0.99 . This means that aerosol particles measured at Mt. Cimone were neutralized. The average NR-PM 1 mass during the campaign was $4.5 \pm 3.4 \mu \mathrm{g} \mathrm{m}^{-3}$, in fairly good agreement with $\mathrm{PM}_{1}$ measurements previously performed at the site in the same season, even though with different measurement techniques (Marenco et al., 2006; Carbone et al. 2010, 2014). The lowest aerosol mass concentrations were observed during the first days of the campaign up to 15 June, when northern Italy was influenced by a low-pressure system, bringing unstable conditions. Conversely, the highest concentrations were recorded between 17 and 20 June under high-pressure conditions characterized by anticyclonic circulation (Decesari et al., 2015), which is known to favour the stagnation of local pollutants produced within the Po Valley basin (see Fig. S2 for further details).

The results of the elemental analysis (EA) of the organic fraction are presented in Fig. 2 as time trends of the $\mathrm{H}: \mathrm{C}$, $\mathrm{O}: \mathrm{C}$ and $\mathrm{OM}: \mathrm{OC}$ ratios. Average $\mathrm{H}: \mathrm{C}, \mathrm{O}: \mathrm{C}$ and $\mathrm{OM}: \mathrm{OC}$

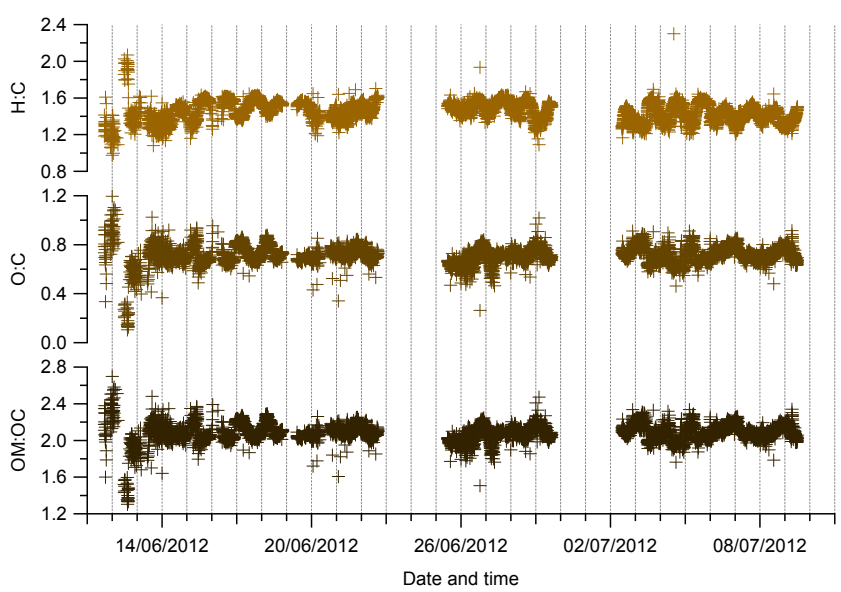

Figure 2. Time series of the $\mathrm{H}: \mathrm{C}, \mathrm{O}: \mathrm{C}$ and $\mathrm{OM}$ : $\mathrm{OC}$ ratios. Time is local (UTC $+2 \mathrm{~h})$.

ratio measured during the campaign are $1.45 \pm 0.11$, $0.71 \pm 0.08$ and $2.08 \pm 0.10$, respectively, corresponding to an average oxidation state $\left(\mathrm{OS}_{\mathrm{C}}=2 \times \mathrm{O}: \mathrm{C}-\mathrm{H}: \mathrm{C}\right.$; Kroll et al., 2011) of $-0.02 \pm 0.23$. These ratios are indicative of a highly oxygenated organic aerosol, in agreement with previous AMS measurements at mountain sites (Freney et al., 2011; Lanz et al., 2010). The values have been calculated using the Improved-Ambient (I-A) EA method to derive OA elemental ratios from AMS spectra (Canagaratna et al., 2015).

The corresponding EA values calculated using the AikenAmbient (A-A) method (Aiken et al., 2008), are 1.32 \pm 0.08 , $0.58 \pm 0.07$ and $1.89 \pm 0.09$, respectively, corresponding to an average oxidation state $\left(\mathrm{OS}_{\mathrm{C}}=2 \times \mathrm{O}: \mathrm{C}-\mathrm{H}: \mathrm{C}\right)$ of $-0.16 \pm 0.22$. The elemental ratios calculated with the A-A method are reported here just for the purpose of a more direct comparison with papers published before the introduction of the new I-A method (2015). Anyway, through all the paper and in the plots, the more accurate I-A elemental ratios will be reported. Saarikoski et al. (2012) present results of HR-ToF-AMS measurements in the Po Valley at the site of San Pietro Capofiume (SPC) during April 2008, showing an average $\mathrm{H}: \mathrm{C}$ ratio slightly higher (1.49) and an average $\mathrm{O}: \mathrm{C}$ ratio slightly lower $(0.47)$ than those observed at Mt. Cimone, for a resulting average OM : OC ratio of 1.77 . Similarly, OM : OC higher than 1.7 was observed in the outflow plume over Mexico City and at the mountain site of Altzomoni, above the Mexico City plateau (Gilardoni et al., 2009). The OM: OC ratio observed at SPC in fall 2011 was 1.6 (Gilardoni et al., 2014). The lower oxidation of the OA collected at SPC during spring and fall with respect to the present measurements can be due to (a) the different season or (b) oxidation processes involving OA during transport from low-altitude sites up to Mt. Cimone. This last aspect will be investigated in Sect. 3.3. 
Table 1. Summary of AMS measurements at mountain sites published in the literature. Concentrations are expressed in $\mu \mathrm{g} \mathrm{m}{ }^{-3}$.

\begin{tabular}{|c|c|c|c|c|c|c|c|c|c|c|}
\hline Reference & $\begin{array}{l}\text { Site/ } \\
\text { season }\end{array}$ & $\begin{array}{l}\text { Altitude } \\
\text { (m a.s.l.) }\end{array}$ & Organics & Nitrate & Sulfate & Ammonium & Chloride & $\mathrm{H}: \mathrm{C}$ & $\mathrm{O}: \mathrm{C}$ & OM : OC \\
\hline Hock et al. (2008) & $\begin{array}{l}\text { Hohenpeissenberg/ } \\
\text { spring }\end{array}$ & 985 & $\begin{array}{r}3.4 \\
(50 \%)\end{array}$ & $\begin{array}{r}1.3 \\
(19 \%)\end{array}$ & $\begin{array}{r}1.3 \\
(19 \%)\end{array}$ & $\begin{array}{r}0.7 \\
(11 \%)\end{array}$ & $\begin{array}{r}0.07 \\
(1 \%)\end{array}$ & - & - & - \\
\hline Sun et al. (2009) & $\begin{array}{l}\text { Whistler Mountain/ } \\
\text { spring }\end{array}$ & 2182 & $\begin{array}{r}1.05 \pm 1.03 \\
(55 \%)\end{array}$ & $\begin{array}{r}0.05 \pm 0.10 \\
(3 \%)\end{array}$ & $\begin{array}{r}0.58 \pm 0.41 \\
(30 \%)\end{array}$ & $\begin{array}{r}0.23 \pm 0.16 \\
(12 \%)\end{array}$ & - & $1.66 \pm 0.06$ & $0.83 \pm 0.17$ & $2.28 \pm 0.23$ \\
\hline Lanz et al. (2010) & $\begin{array}{l}\text { Jungfraujoch/ } \\
\text { spring }\end{array}$ & 3580 & $\begin{array}{r}0.7 \\
(43 \%)\end{array}$ & $\begin{array}{r}0.3 \\
(18 \%)\end{array}$ & $\begin{array}{r}0.4 \\
(26 \%)\end{array}$ & $\begin{array}{r}0.2 \\
(13 \%)\end{array}$ & $\begin{array}{r}<0.02 \\
(<1 \%)\end{array}$ & - & - & - \\
\hline Freney et al. (2011) & $\begin{array}{l}\text { Puy de Dôme/ } \\
\text { autumn }\end{array}$ & 1465 & $\begin{array}{r}2.52 \\
(34 \%)\end{array}$ & $\begin{array}{r}1.14 \\
(15 \%)\end{array}$ & $\begin{array}{r}2.4 \\
(32 \%)\end{array}$ & $\begin{array}{r}1.36 \\
(18 \%)\end{array}$ & $\begin{array}{r}0.02 \\
(0.3 \%)\end{array}$ & - & - & - \\
\hline Freney et al. (2011) & $\begin{array}{l}\text { Puy de Dôme/ } \\
\text { winter }\end{array}$ & 1465 & $\begin{array}{r}1.24 \\
(23 \%)\end{array}$ & $\begin{array}{r}1.71 \\
(32 \%)\end{array}$ & $\begin{array}{r}1.28 \\
(24 \%)\end{array}$ & $\begin{array}{r}1.08 \\
(20 \%)\end{array}$ & $\begin{array}{r}0.07 \\
(1 \%)\end{array}$ & - & - & - \\
\hline Freney et al. (2011) & $\begin{array}{l}\text { Puy de Dôme/ } \\
\text { summer }\end{array}$ & 1465 & $\begin{array}{r}15.59 \\
(57 \%)\end{array}$ & $\begin{array}{r}2.33 \\
(9 \%)\end{array}$ & $\begin{array}{r}5.45 \\
(20 \%)\end{array}$ & $\begin{array}{r}3.69 \\
(14 \%)\end{array}$ & $\begin{array}{r}0.06 \\
(0.2 \%)\end{array}$ & - & - & - \\
\hline This study & $\begin{array}{l}\text { Mt. Cimone/ } \\
\text { summer }\end{array}$ & 2165 & $\begin{array}{r}2.8 \pm 2.4 \\
(63 \%)\end{array}$ & $\begin{array}{r}0.33 \pm 0.46 \\
(7 \%)\end{array}$ & $\begin{array}{r}0.92 \pm 0.60 \\
(20 \%)\end{array}$ & $\begin{array}{r}0.41 \pm 0.33 \\
(9 \%)\end{array}$ & $(<1 \%)$ & $1.45 \pm 0.11$ & $0.71 \pm 0.08$ & $2.08 \pm 0.10$ \\
\hline
\end{tabular}

\subsection{Analysis of the diurnal cycles}

The atmospheric concentrations of the major NR-PM 1 components present a clear diurnal cycle with maxima at the early afternoon and minima during the night (Fig. 3). The concentration daily trend of the NR-PM 1 components is the result of the PBL dynamics and valley breezes, as during the night the site is well above the shallow nocturnal layer forming over the Po Valley plain and disconnected from the aerosol sources located at the low altitudes. However, Marinoni et al. (2008) showed that in summer, during the night, Mt. Cimone station may be affected by polluted air masses present in the residual layer above the Po Valley. Conversely, during the day, with the increase of the PBL height, the site is affected by convective transport from lower altitudes (Schuepbach et al., 2001; Fischer et al., 2003; Freney et al., 2011) and it is directly connected to the pollution sources located in the valley, thus experiencing high aerosol concentrations. During PEGASOS, the time trend of OA (the major contributor to NR-PM ${ }_{1}$ ) correlates with that of specific humidity ( $\mathrm{SH}$ ), which can be used as a tracer of PBL air at high altitudes (Henne et al., 2005) (Fig. S3). This good correlation strongly supports the hypothesis that the aerosol transport triggered by the PBL dynamics is the main factor regulating the NR$\mathrm{PM}_{1}$ concentrations at Mt. Cimone during the measurement period.

To further investigate the importance of vertical transport from the PBL to the top of Mt. Cimone during the day, we calculated the daily relative increase (RI) in $\mathrm{SH}$, following the approach introduced by Prévôt et al. (2000) and Henne et al. (2005) for two different sites in the Alps and already applied for Mt. Cimone station by Carbone et al. (2014).

$\mathrm{RI}=\frac{\mathrm{SH}_{\mathrm{aft}}(\mathrm{CMN})-\mathrm{SH}_{\mathrm{mor}}(\mathrm{CMN})}{\mathrm{SH}_{\mathrm{aft}}(\mathrm{SPC})-\mathrm{SH}_{\mathrm{mor}}(\mathrm{CMN})}$

In Eq. (1), $\mathrm{SH}_{\mathrm{atf}}(\mathrm{CMN})$ is the average specific humidity measured in the afternoon at Mt. Cimone (12:00 to 18:00 LT), $\mathrm{SH}_{\text {mor }}(\mathrm{CMN})$ is the average specific humidity measured during the night at Mt. Cimone (22:00 to 05:00 LT) and $\mathrm{SH}_{\mathrm{aft}}(\mathrm{SPC})$ is the average specific humidity measured in the afternoon (12:00 to 18:00 LT) at the rural background station of San Pietro Capofiume (SPC), located in the Po Valley $90 \mathrm{~km}$ north-east of Mt. Cimone at $11 \mathrm{~m}$ a.s.l. and considered representative of PBL conditions within the Po Valley basin. A RI of 1 corresponds to a complete replacement of the highaltitude air by boundary layer air, while no vertical motion yields zero relative increase. RI was calculated for each day of the campaign and the average value was $0.8 \pm 0.3$, confirming the high influence of vertical convection during the day at the station in summer.

Similarly to the NR-PM 1 components, OA elemental ratios exhibit diurnal variations (Fig. 4). The $\mathrm{O}: \mathrm{C}$ and $\mathrm{OM}$ : OC ratios have lower values in the afternoon and maxima at night, with a minimum $\mathrm{O}: \mathrm{C}$ hourly average of $0.67 \pm 0.10$ observed between 14:00 and 15:00, and maximum of $0.75 \pm 0.08$ between 00:00 and 01:00. An opposite trend is observed for the $\mathrm{H}: \mathrm{C}$ ratio, with a maximum hourly average of $1.55 \pm 0.10$ between 14:00 and 15:00, and a minimum of $1.38 \pm 0.10$ between 00:00 and 01:00. The daily trends of the $\mathrm{O}: \mathrm{C}$ and $\mathrm{OM}: \mathrm{OC}$ ratios are almost coincident (correlation coefficient 0.999 ), confirming the results of Pang et al. (2006) showing that the OM:OC ratio is mainly regulated by the $\mathrm{O}: \mathrm{C}$ ratio.

These trends highlight the different age of the aerosols measured at the sampling location in different moments of the day, as a consequence of the PBL dynamics. In fact, the $\mathrm{O}: \mathrm{C}$ ratio of $\mathrm{OA}$ tends to increase and the $\mathrm{H}: \mathrm{C}$ ratio decreases as a function of its atmospheric residence time, because of the oxidation of reduced species emitted by traffic and combustion and of SOA formation (Aiken et al., 2008; DeCarlo et al., 2008; Heald et al., 2010; Chhabra et al., 2011; $\mathrm{Ng}$ et al., 2011; Sun et al., 2011b, a). Particles sampled at Mt. Cimone during the day are representative of an early stage of aerosol atmospheric oxidation, resulting from SOA formed at lower altitudes in the Po Valley and transported upward by turbulence and by thermal winds, typically in few hours. By contrast, at night the aerosol sampled at Mt. Ci- 

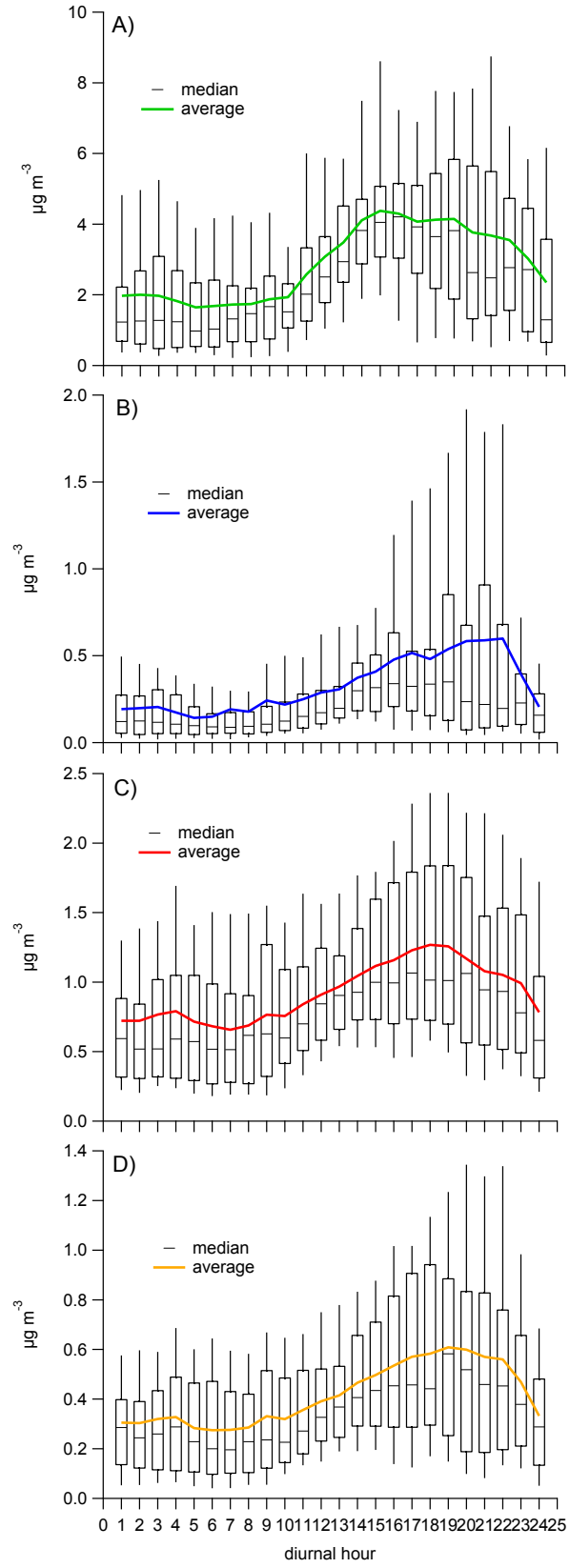

Figure 3. Daily trends of (a) organics, (b) nitrate, (c) sulfate and (d) ammonium. Boxes represent median, 25th and 75th percentile; whiskers indicates 10th and 90th percentile. Time is local $(\mathrm{UTC}+2 \mathrm{~h})$.

mone is more processed, as the atmospheric layers affecting the site at night contain aerosols with an age of several hours (residual layers) to days (from long-range transport). This is confirmed by the $\mathrm{CO} / \mathrm{NO}_{x}$ ratio, often used in the literature as a tracer for air mass photochemical age (Morgan et al., 2010; Freney et al., 2011). CO / $\mathrm{NO}_{x}$ at Mt. Cimone is $159 \pm 65$ (average \pm standard deviation) during the day and $287 \pm 168$ at night, which is a value representative
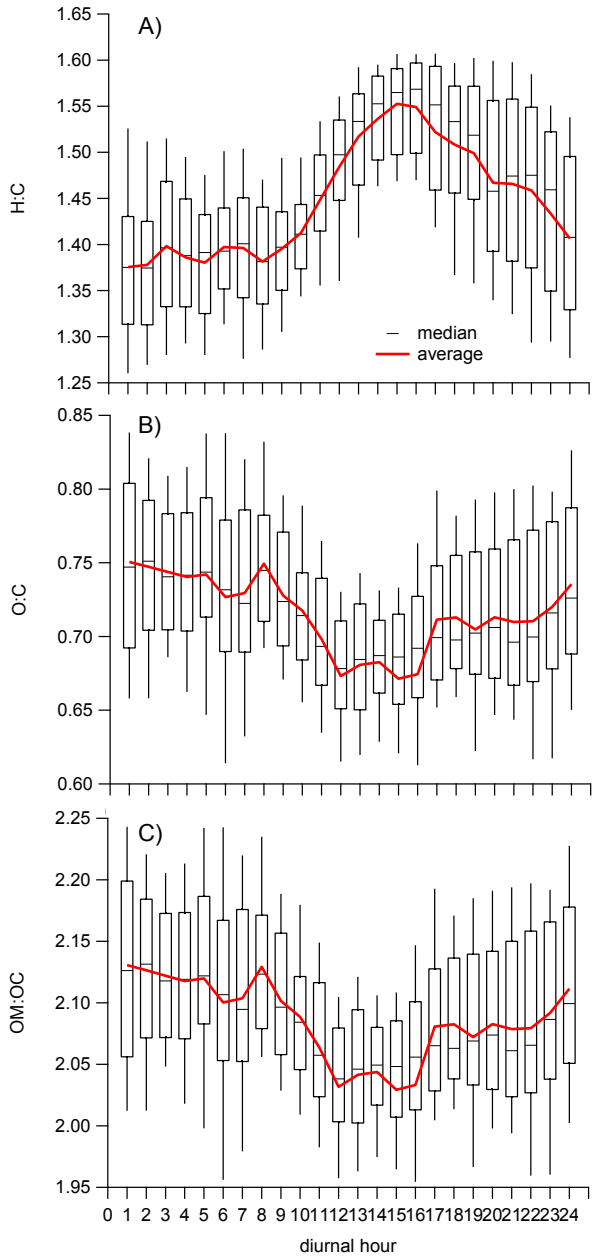

Figure 4. Daily trends of the (a) $\mathrm{H}: \mathrm{C}$, (b) $\mathrm{O}: \mathrm{C}$ and (c) $\mathrm{OM}: \mathrm{OC}$ ratios. Boxes represent median, 25 th and 75 th percentile; whiskers indicates 10th and 90th percentile. Time is local (UTC $+2 \mathrm{~h})$.

of aged regional emissions. The $\mathrm{CO} / \mathrm{NO}_{x}$ ratio is presented in detail in Fig. S4, showing clearly that during the night the $\mathrm{CO} / \mathrm{NO}_{x}$ ratio is systematically higher than during the day. For these reasons, Mt. Cimone is an ideal site to investigate the processing of organic aerosol over the Po Valley basin. Moreover, according to Marinoni et al. (2008), the footprint of aerosol particles found in the residual layers at night comprises a great part of central Europe, which is the region where the full oxidation of organic aerosols that we observe at Mt. Cimone takes place.

\subsection{Investigation of regional scale organic aerosol ageing}

To investigate the oxidation of OA, data collected at Mt. Cimone during the campaign have been divided based on the position of the station relative to the PBL height, using SH as a tracer of the PBL evolution. Figure S5 shows the average daily evolution of the SH at Mt. Cimone during the campaign 


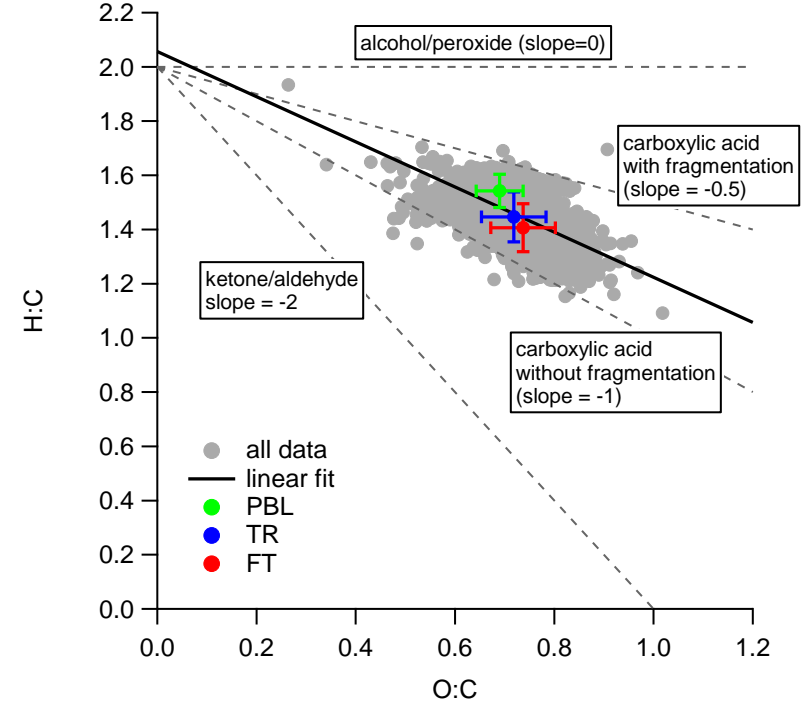

Figure 5. Van Krevelen diagram presenting the $\mathrm{H}: \mathrm{C}$ and $\mathrm{O}: \mathrm{C}$ ratios of all the data points collected during the campaign, together with average values for PBL, TR and FT samples. The solid line represents the fit to the data (not constrained to $\mathrm{H}: \mathrm{C}=2$ ). Dashed lines describes oxidation reactions occurring through addition of carbonyl groups (slope $=-2$; Heald et al., 2010), carboxylic acid without fragmentation (slope $=-1$; Heald et al., 2010), carboxylic acid with fragmentation (slope $=-0.5 ; \mathrm{Ng}$ et al., 2011) and alcohol/peroxide (slope $=0$; Heald et al., 2010).

that mimics the PBL evolution during the day: the afternoon maximum indicates that the site is within the PBL, under the influence of moist air coming from lower altitudes, while the night minimum indicates that Mt. Cimone station is above the PBL. Following Fig. S5, HR-ToF-AMS measurements collected between 12:00 and 18:00 have been considered as PBL samples, those collected between 22:00 and 05:00 have been defined as free troposphere (FT) samples, while all the samples excluded from the previous two groups have been considered as transition samples (TR). As expected, PBL samples were less oxidized $(\mathrm{H}: \mathrm{C}=1.54 \pm 0.06$, $\mathrm{O}: \mathrm{C}=0.69 \pm 0.05, \quad \mathrm{OM}: \mathrm{OC}=2.05 \pm 0.10) \quad$ than $\mathrm{FT}$ samples $\quad(\mathrm{H}: \mathrm{C}=1.41 \pm 0.09, \quad \mathrm{O}: \mathrm{C}=0.74 \pm 0.07$, $\mathrm{OM}: \mathrm{OC}=2.12 \pm 0.10)$, with $\mathrm{TR}$ samples characterized by intermediate values $(\mathrm{H}: \mathrm{C}=1.45 \pm 0.09$, $\mathrm{O}: \mathrm{C}=0.72 \pm 0.07, \quad \mathrm{OM}: \mathrm{OC}=2.08 \pm 0.09), \quad$ consistent with the average elemental ratios discussed in Sect. 3.1. The differences between the average elemental ratios of PBL, TR and FT are statistically significant according to the t-test $(p<0.01)$. The large standard deviations associated to the mean values are due to day-by-day variations, as showed by Fig. S6. Figure S6 also shows that, independently of the day-by-day variations, $\mathrm{O}: \mathrm{C}$ is systematically higher, and $\mathrm{H}: \mathrm{C}$ systematically lower, in the FT compared to the PBL air masses, while the TR air masses have intermediate values.

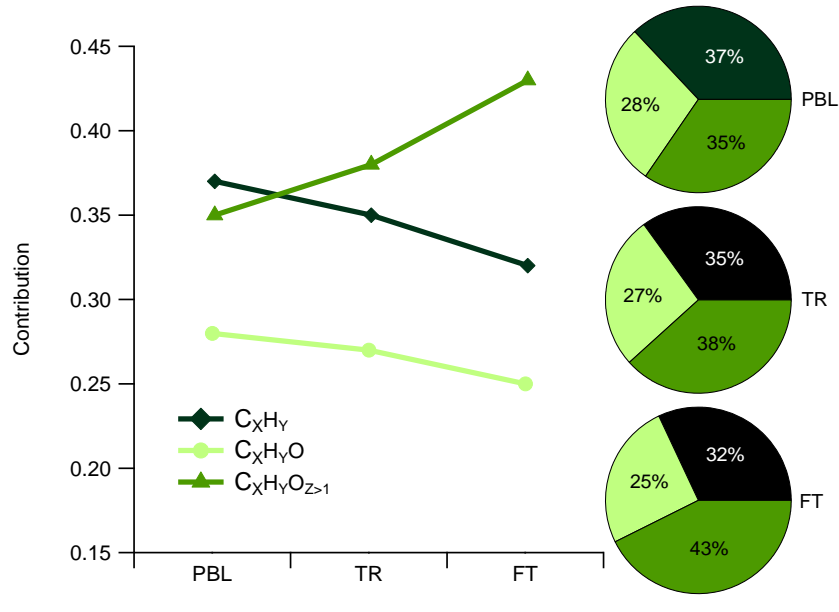

Figure 6. Contribution of organic fragments containing only carbon and hydrogen $\left(\mathrm{C}_{x} \mathrm{H}_{y}\right)$, organic fragments containing carbon, hydrogen and one oxygen atom $\left(\mathrm{C}_{x} \mathrm{H}_{y} \mathrm{O}_{1}\right)$ and organic fragments containing carbon, hydrogen and more than one oxygen atom $\left(\mathrm{C}_{x} \mathrm{H}_{y} \mathrm{O}_{z>1}\right)$ in PBL, TR and FT samples.

Figures 5 shows the whole campaign data points in a Van Krevelen diagram (Van Krevelen, 1950), together with the average $\mathrm{H}: \mathrm{C}$ and $\mathrm{O}: \mathrm{C}$ ratios of PBL, TR and FT samples. The data are lumped within the region delimited by $\mathrm{O}: \mathrm{C}$ between 0.5 and 1 and $\mathrm{H}: \mathrm{C}$ between 1.1 and 1.5. The plot illustrates the process of $\mathrm{OA}$ atmospheric oxidation in the investigated area characterized by a slope comprised between -0.5 and -1 . According to Heald et al. (2010) and $\mathrm{Ng}$ et al. (2011), such an intermediate slope can result from a combination of reactions adding carboxylic acids to the OA, occurring both with and without fragmentation of the parent molecules (expected slopes $=-0.5$ and -1 , respectively). Kroll et al. (2011) reported that fragmentation becomes increasingly important for already oxidized material undergoing further processing. This can explain the results at $\mathrm{Mt}$. Cimone, where OA does not resemble recently formed secondary material, in analogy with $\mathrm{Ng}$ et al. (2011). An alternative explanation for a slope tending to -0.5 is given by equivalent amounts of addition of carboxylic groups and of hydroxyls or peroxides ( $\mathrm{Ng}$ et al., 2011).

The addition of carboxylic functionalities during the OA ageing process is confirmed by the analysis of the highresolution mass fragments, showing that from PBL to FT samples, the average contribution of $\mathrm{C}_{x} \mathrm{H}_{y} \mathrm{O}_{z>1}$, attributed to the fragmentation of carboxylic structures (Aiken et al., 2007; Takegawa et al., 2007; Duplissy et al., 2011), increases from 35 to $43 \%$, while both $\mathrm{C}_{x} \mathrm{H}_{y}$ and $\mathrm{C}_{x} \mathrm{H}_{y} \mathrm{O}$ fragments decrease (Fig. 6). The mean elemental compositions calculated for PBL, TR and FT samples fall at distinct positions along the line of average ageing in the Van Krevelen space (Fig. 5), suggesting that the observed oxidation of $\mathrm{OA}$ is dictated by 

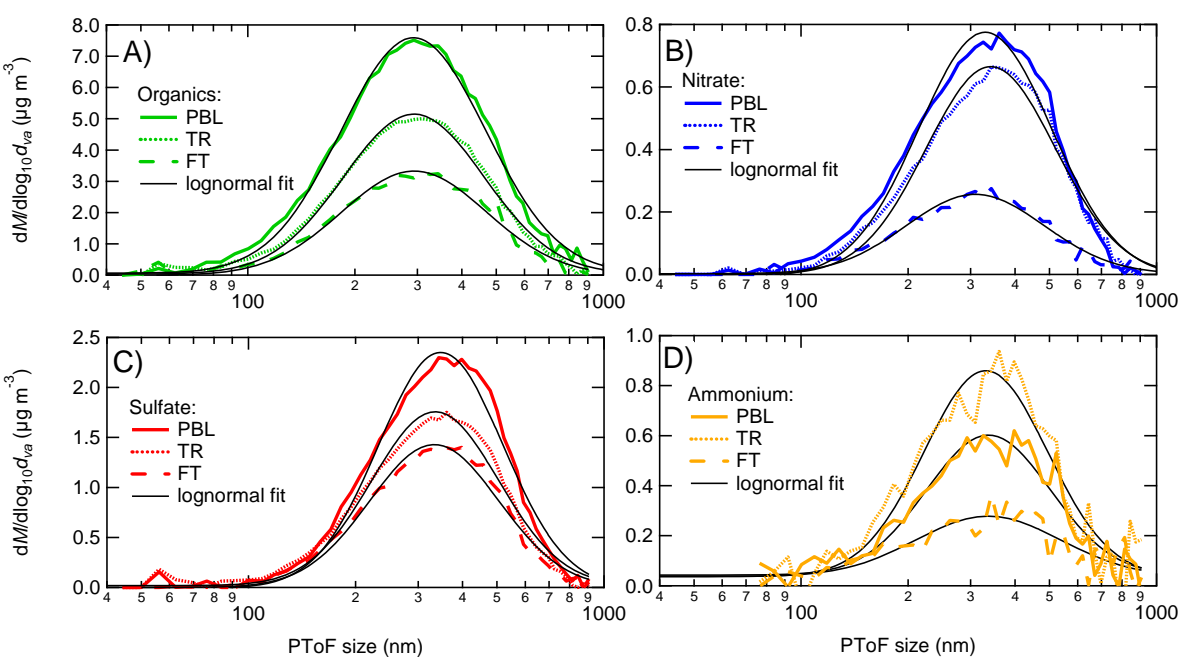

Figure 7. Size distribution of (a) organics, (b) nitrate, (c) sulfate and (d) ammonium in PBL, TR and FT samples. Log-normal fits are reported as black lines.

Table 2. Pearson correlation coefficients $(R)$ between the time series of the three PMF factors and several gas-phase and particle tracers measured at Mt. Cimone. $T=$ air temperature, $P=$ atmospheric pressure, $\mathrm{RH}=$ relative humidity, $\mathrm{WS}=$ wind speed, $\mathrm{UVB}=\mathrm{UVB}$ radiation flux.

\begin{tabular}{rrrrrrrrrrrrr}
\hline & BC & $\mathrm{CO}$ & $T$ & $P$ & $\mathrm{RH}$ & $\mathrm{WS}$ & $\mathrm{UVB}$ & $\mathrm{O}_{3}$ & $\mathrm{NO}_{x}$ & Nitrate & Sulfate & Ammonium \\
\hline OOAa & 0.54 & 0.71 & 0.48 & 0.42 & 0.22 & -0.23 & 0.12 & 0.45 & 0.70 & 0.55 & 0.48 & 0.57 \\
OOAb & 0.35 & 0.27 & 0.36 & 0.25 & -0.01 & 0.02 & 0.09 & 0.28 & 0.18 & 0.09 & 0.64 & 0.43 \\
OOAc & 0.41 & 0.24 & 0.16 & 0.26 & -0.12 & 0.12 & -0.10 & 0.58 & 0.02 & 0.12 & 0.49 & 0.38 \\
\hline
\end{tabular}

the different age of the aerosols reaching the station at different times of the day, as also evidenced by Fig. S6.

Finally, Fig. 7 shows the time-of-flight particle size distributions (pToF) of the main NR-PM 1 components as measured by the HR-ToF-AMS observed during the three regimes (PBL, TR and RL). For each species, there is no appreciable size distribution difference between the three sample subsets (PBL, TR and FT). However, the pToF of organics peak at a slightly lower $d_{\mathrm{va}}(293 \mathrm{~nm})$ compared to sulfate, ammonium and nitrate (which peak between 330 and $340 \mathrm{~nm} d_{\mathrm{va}}$ ), as determined by a log-normal fit of the size distributions. This result indicates that the organic and inorganic components in all the sampled air masses are not entirely internally mixed. Furthermore, the pToF of organics show a tail towards smaller particles sizes reaching $90 \mathrm{~nm}$, and appreciable amount of mass below $200 \mathrm{~nm} d_{\mathrm{va}}$, which is consistent with previous observations of pToF of organics typically having lower $d_{\mathrm{va}}$ than e.g. $\mathrm{SO}_{4}$, due to different sources and formation processes. It is possible that a fraction of the organics observed at $d_{\mathrm{va}}<200 \mathrm{~nm}$ arises from the growth of smaller particles (fresh emission typically peak at $d_{\mathrm{va}}$ of $80-100 \mathrm{~nm}$ ) via condensation processes during transport to high altitude.

\subsection{OA source apportionment by PMF}

In order to further characterize the OA collected at Mt. Cimone, PMF was applied to the high-resolution OA mass spectra. We screened various solutions with a number of factors from two to ten. A four-factor solution with rotational forcing parameter $f_{\text {peak }}=0\left(Q / Q_{\exp }=2.3\right)$ was chosen, yielding four different types of OOA, two of which were recombined into one factor, because of coincident time series and profiles (Fig. S6). The OA components from the PMF analysis were identified by their mass spectra, elemental composition (Fig. 8) and diurnal cycles (Fig. 9), as well as by correlations of their time series with tracers (Table 2). A detailed summary of key diagnostic plots of the PMF results and a discussion of the factor solution choices can be found in the Supplement.

The three resulting factors are all of the oxygenated organic aerosol (OOA) type and have been defined as OOAa, OOAb and OOAc. No "standard" hydrocarbon like (HOA) factor (i.e. with $m / z 43 \gg m / z 44$ and with a significant amount of hydrocarbon-like ions, $\mathrm{C}_{x} \mathrm{H}_{y}$ ) could be extracted by PMF, similarly to other AMS data sets collected at background sites (Hildebrandt et al., 2010; Freney et al., 2011), indicating almost no direct influence of freshly emitted primary aerosols to the observed OA load. This result is con- 


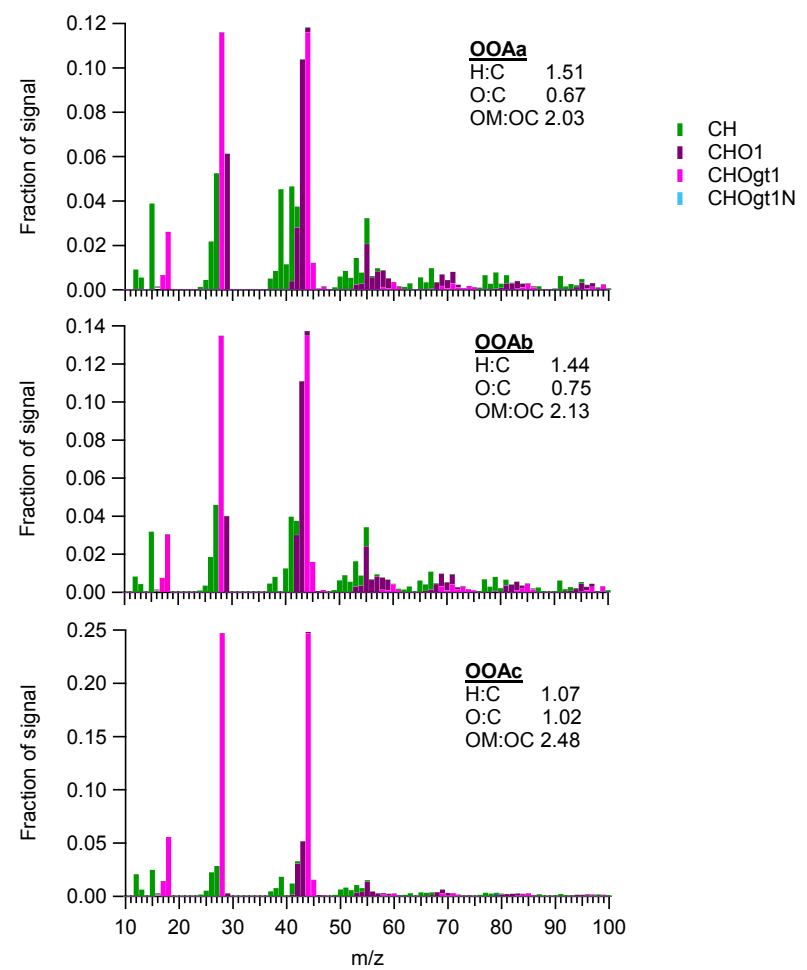

Figure 8. High-resolution mass spectra of the three factors extracted by PMF. Insets in each plot report the results of the elemental analysis (from the I-A method).

sistent with the highly oxidized character of the OA, as described previously. Even though $m / z 44\left(\mathrm{CO}_{2}^{+}\right)$dominates the mass spectra of all the three factors, the OOAa factor has a slightly higher amount of $\mathrm{C}_{x} \mathrm{H}_{y}$ ions at $m / z 27\left(\mathrm{C}_{2} \mathrm{H}_{3}^{+}\right), 39$ $\left(\mathrm{C}_{3} \mathrm{H}_{3}^{+}\right), 41\left(\mathrm{C}_{3} \mathrm{H}_{5}^{+}\right)$compared to the other factors.

The elemental composition $(\mathrm{H}: \mathrm{C}, \mathrm{O}: \mathrm{C})$ and the $\mathrm{OM}: \mathrm{OC}$ ratio are also reported in Fig. 8. OOAc is the most oxidized factor, with an $\mathrm{OM}: \mathrm{OC}$ ratio of 2.48 vs. 2.03 and 2.13 of OOAa and OOAb, respectively. Consequently, it has higher $\mathrm{O}: \mathrm{C}(1.02)$ and lower $\mathrm{H}: \mathrm{C}(1.07)$ ratios than OOAa $(0.67 ; 1.51)$ and OOAb $(0.75 ; 1.44)$. OOAa average concentration was $1.5 \pm 1.7 \mu \mathrm{g} \mathrm{m}^{-3}$ during the campaign, which accounts for $55 \%$ of the OA. OOAb presented higher concentrations during the period 17-23 June $\left(2.1 \pm 1.5 \mu \mathrm{g} \mathrm{m}^{-3}\right)$ and low concentrations during the rest of the campaign $\left(0.27 \pm 0.29 \mu \mathrm{g} \mathrm{m}^{-3}\right)$, for an average concentration of $0.67 \pm 1.1 \mu \mathrm{g} \mathrm{m}^{-3}$ and a contribution of $25 \%$. The concentration of OOAc was $0.54 \pm 0.40 \mu \mathrm{g} \mathrm{m}^{-3}$, contributing $20 \%$ on average to the OA.

When looking at the diurnal profiles of the three factors (Fig. 9), we see clear diurnal cycles for OOAa and OOAc (but with opposite trends, OOAa having a maximum at 16:00, and OOAc having a minimum at 14:00) and a less pronounced diurnal profile for OOAb (slightly higher concentration around 12:00-14:00 than during the rest of the day). The fact that OOAa concentration is much higher during the day than at
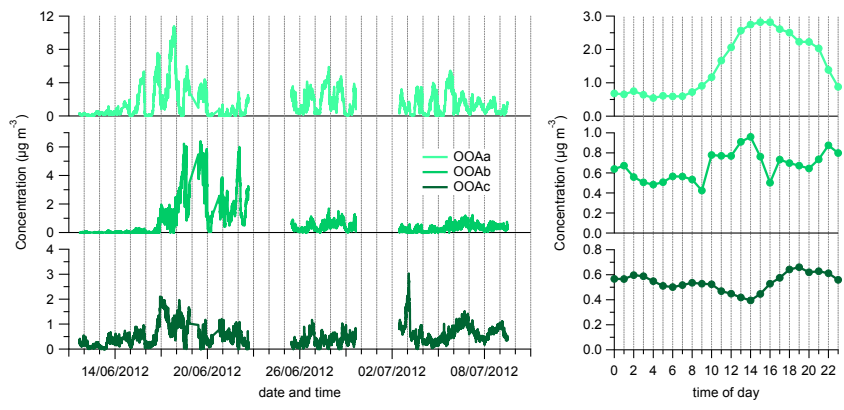

Figure 9. Time series and diurnal trend of the three factors extracted by PMF.

night indicates that this factor derives from sources located within the PBL and is transported at Mt. Cimone by convection and by thermal winds in daytime, as discussed above. Conversely, the trend for OOAc with lower concentrations during the day points to a transport from the free troposphere, or in any case from above the PBL.

The Pearson correlation coefficients $(R)$ between the three PMF factors and several external gas-phase and particle tracers are reported in Table 2. OOAa correlates best with $\mathrm{CO}$, $\mathrm{NO}_{x}$ and $\mathrm{BC}(0.71,0.70$ and 0.54 , respectively), which are attributable to anthropogenic sources located within the PBL, confirming our interpretation of the OOAa source location. OOAb shows lower correlation than OOAa against all the tracers, with higher $R$ values associated with the above enlisted PBL tracers $\left(\mathrm{CO}, \mathrm{NO}_{x}\right.$ and $\left.\mathrm{BC}\right)$, suggesting that this factor was contributed by PBL sources too. Interestingly, $\mathrm{OOAb}$ presents the highest correlation with sulfate, which suggests a regional character for this OOA component. The highest correlation for OOAc is with $\mathrm{O}_{3}$, with a very small correlation with all the PBL tracers. The high correlation of OOAc with $\mathrm{O}_{3}$ is mainly driven by the coincident daily trends (Fig. S11), showing higher concentration at night, a typical feature of $\mathrm{O}_{3}$ at high-altitude sites (Fischer et al., 2003; Cristofanelli et al., 2007). In fact, during summer, air masses richer in photochemically produced $\mathrm{O}_{3}$ are vented to Mt. Cimone in the afternoon, leading to an increase of $\mathrm{O}_{3}$ until evening, when $\mathrm{O}_{3}$ observations start to be more representative of the free troposphere.

The spectral and elemental features of the three OOA factors are in the range of others reported in the literature (Mohr et al., 2012; Holzinger et al., 2013; Sun et al., 2011a). Similar OOA spectra have also been described by Saarikoski et al. (2012) for the Po Valley site of San Pietro Capofiume. Correlation analysis with reference high-resolution spectra (Table 3) suggests that all the OOA components identified can be classified as LV-OOA (low volatile-OOA). However, OOAa and OOAb present qualitatively similar spectral features to the SV-OOA (semi volatile-OOA) reported by Freney et al. (2011), for a similar high-altitude station, and by Hayes et al. (2013), for photochemically aged aerosol. The 
Table 3. Pearson correlation coefficients $(R)$ between the profiles of the three PMF factors and reference high-resolution factor profiles found in the literature.

\begin{tabular}{|c|c|c|c|c|c|c|c|c|c|c|c|c|c|}
\hline & \multicolumn{6}{|c|}{ Saarikoski et al. (2012) } & \multicolumn{4}{|c|}{ Mohr et al. (2012) } & \multicolumn{3}{|c|}{ Crippa et al. (2013) } \\
\hline & OOAa & $\mathrm{OOAb}$ & OOAc & HOA & BBOA & NOA & BBOA & HOA & LVOA & SVOA & SVOOA & LVOOA & $\mathrm{HOA}$ \\
\hline OOAa & 0.93 & 0.92 & 0.90 & 0.75 & 0.38 & 0.40 & 0.62 & 0.19 & 0.87 & 0.81 & 0.86 & 0.93 & 0.50 \\
\hline OOAb & 0.94 & 0.92 & 0.90 & 0.70 & 0.30 & 0.34 & 0.61 & 0.17 & 0.91 & 0.81 & 0.81 & 0.93 & 0.45 \\
\hline OOAc & 0.97 & 0.94 & 0.97 & 0.58 & 0.21 & 0.10 & 0.31 & 0.07 & 0.95 & 0.76 & 0.59 & 0.94 & 0.32 \\
\hline
\end{tabular}
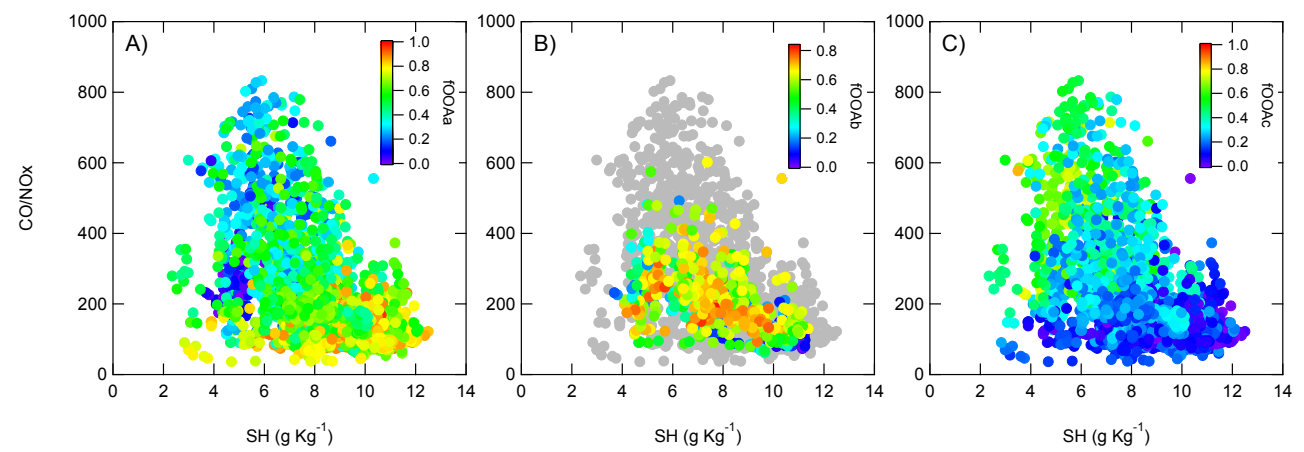

Figure 10. $\mathrm{CO} / \mathrm{NO}_{x}$ ratio vs. $\mathrm{SH}$, colour-coded by the contribution of factors (a) OOAa, (b) OOAb and (c) OOAc. In panel (b) only the data points corresponding to OOAb maximum contribution period (17-23 June) have been coloured, to make the plot clearer.

$f_{44}$ (contribution of organic mass fragments with $\mathrm{m} / \mathrm{z} 44$ ) of OOAa and OOAb is 0.13 and 0.14 , respectively, which is across the SV-OOA/LV-OOA region proposed by Cubison et al. (2011). Therefore, we believe that OOAa and OOAb can be considered either as highly oxidized SV-OOA or LV-OOA with a low oxidation level.

In summary, OOAa is clearly attributed to sources or formation processes located within the PBL that reach the station when vertical transport (PBL convection and valley/upslope breeze) is maximized. OOAa is the less oxidized factor retrieved by PMF and likely represents a moderately aged local OA. OOAb has a less defined diurnal cycle (still with maximum during the day) and a slightly higher $\mathrm{O}: \mathrm{C}$ ratio than OOAa. The period of OOAb maximum contribution coincides with meteorological conditions characterized by reduced horizontal air motion and dominated by breeze regimes (17-23 June, when an anticyclonic high-pressure system was present over northern Italy). These conditions favour the accumulation of pollutants within the PBL and in the residual layers above, because of reduced air circulation. Collaud Coen et al. (2011) demonstrated that under such meteorological conditions, air masses from residual layers continue to influence the Jungfraujoch high-altitude station also during the night, leading to higher minima in the diurnal aerosol concentration than in other conditions. We postulate that the same happens at Mt. Cimone. The entire region influenced by the high-pressure system extends beyond the Po Valley basin, comprising the great Alpine region. Over the Alps, orographic lifting of PBL air is responsible for the formation of residual layers at very high altitudes (the Jungfrau- joch is at $3571 \mathrm{~m}$ a.s.1.) which can then travel on the top of the PBL over the surrounding basins (like the Po Valley). We therefore hypothesize that factor OOAb is a regional com-

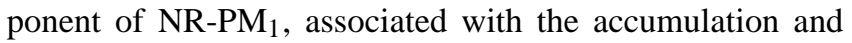
ageing of OA in residual layers when wind speeds are small throughout the lower troposphere during the period of enhanced high-pressure conditions. This is also supported by the good correlation between OOAb and regional sulfate.

Finally, OOAc is the product of prolonged atmospheric processing of OA, occurring mainly in the free troposphere, and can be considered as representative of the background FT OA on a spatial scale that comprises all western European areas upwind of Mt. Cimone. These conclusions are confirmed by the plots in Fig. 10, showing $\mathrm{CO} / \mathrm{NO}_{x}$ vs. SH, colourcoded by the contribution of each factor. Clearly, OOAa is associated with air masses characterized by reduced photochemical age (low $\mathrm{CO} / \mathrm{NO}_{x}$ ) and strongly influenced by the PBL (high SH), while OOAc contributes more in air masses characterized by high photochemical age (high $\mathrm{CO} / \mathrm{NO}_{x}$ ) and less influenced by the PBL (low SH). OOAb presents intermediate characteristics (mid- to low- $\mathrm{CO} / \mathrm{NO}_{x}$ and intermediate $\mathrm{SH}$ ), consistent with the hypothesis that $\mathrm{OOAb}$ is representative of OA of intermediate age that is accumulated in the residual layers during the period of high pressure, due to the stagnant atmospheric conditions. 


\section{Conclusions}

The chemical composition of non-refractory submicrometric particles was measured for the first time by a HR-ToF-AMS at the Mt. Cimone GAW/WMO high-altitude station. Submicrometric aerosol was dominated by the organic fraction (on average $63 \%$ ), with ammonium sulfate as the second contributor, for an average NR-PM 1 mass of $4.5 \pm 3.4 \mu \mathrm{g} \mathrm{m}^{-3}$. Elemental analysis of the high-resolution AMS data showed highly oxygenated $\mathrm{OA}$ (the campaign-average $\mathrm{H}: \mathrm{C}, \mathrm{O}: \mathrm{C}$ and $\mathrm{OM}: \mathrm{OC}$ were $1.45 \pm 0.11,0.71 \pm 0.08$ and $2.08 \pm 0.10$, respectively), suggesting that strong oxidation and SOA formation processes occur during aerosol transport to high altitudes. Different stages of OA processing could be identified when comparing the OA composition during the day, when the station was affected by the upward transport of PBL air, and the night-time, when the site was in the free troposphere (FT).

Analysis of the OA elemental ratios in a Van Krevelen space showed that OA oxidation followed a slope comprised between -0.5 and -1 , consistent with the addition of carboxylic groups to alkyl structures, occurring both with and without fragmentation of the reagent molecules. The increase of carboxylic groups during OA processing and ageing is confirmed by the increased contribution of $\mathrm{C}_{x} \mathrm{H}_{y} \mathrm{O}_{z>1}$ fragments during night-time measurements.

Quantitative information on the contributions of more- and less-aged OA components were achieved by analysing the high-resolution AMS data by positive matrix factorization (PMF). OOAa (55\%), the least oxidized OOA factor, was related to sources or formation processes located within the PBL, reaching the station mainly during the day, when vertical transport is maximized. OOAb $(25 \%)$ was attributed to the accumulation and ageing of OA in the PBL and in the residual layers above the $\mathrm{PBL}$, due to stagnation over the great Alpine region. Finally, OOAc (20\%) was interpreted as the product of prolonged atmospheric processing of OA occurring mainly above the PBL, and can be considered as representative of background free tropospheric OA at a continental scale.

This work highlights the important contribution of organic aerosols to the composition of submicron particles at remote mountain sites. We found that $63 \%$ of the NR-PM 1 mass that constitutes the background aerosol levels for the Po Valley in the summer is accounted for by highly oxygenated organic matter. No important contribution from primary combustion organic particles (HOA) was measured, indicating that these compounds were likely lost during transport, either by evaporation or chemical processing. Most importantly, in spite of the vicinity of strongly emitting pollution sources in the Po Valley, only $55 \%$ of the organic matter measured at Mt. Cimone in the summer could be attributed to sources within the PBL, while the remaining fraction $(45 \%)$ is accounted for by remote upwind sources. This study confirms the importance of regional-scale physical and chemical processes and of transboundary transport in determining the background aerosol composition at rural European sites.

\section{The Supplement related to this article is available online at doi:10.5194/acp-15-11327-2015-supplement.}

Acknowledgements. This work was supported by the projects PEGASOS and BACCHUS funded by the European Commission under the Framework Programme 7 (FP7-ENV-2010-265148 and FP7-603445) and by the project SUPERSITO funded by Regione Emilia-Romagna (DRG no. 428/10). Continuous atmospheric observation programmes at Mt. Cimone are supported by the Project of National Interest NextData, funded by the Italian Ministry for Education, University and Research and by EU-ACTRIS project.

Maria Cristina Facchini is acknowledged for the helpful suggestions. Leone Tarozzi, Francesca Pollini and Francescopiero Calzolari are acknowledged for the technical support.

Edited by: U. Baltensperger

\section{References}

Aiken, A. C., DeCarlo, P. F., and Jimenez, J. L.: Elemental analysis of organic species with electron ionization highresolution mass spectrometry, Anal. Chem., 79, 8350-8358, doi:10.1021/ac071150w, 2007.

Aiken, A. C., Decarlo, P. F., Kroll, J. H., Worsnop, D. R., Huffman, J. A., Docherty, K. S., Ulbrich, I. M., Mohr, C., Kimmel, J. R., Sueper, D., Sun, Y., Zhang, Q., Trimborn, A., Northway, M., Ziemann, P. J., Canagaratna, M. R., Onasch, T. B., Alfarra, M. R., Prevot, A. S. H., Dommen, J., Duplissy, J., Metzger, A., Baltensperger, U., and Jimenez, J. L.: O / C and OM / OC ratios of primary, secondary, and ambient organic aerosols with highresolution time-of-flight aerosol mass spectrometry, Environ. Sci. Technol., 42, 4478-4485, doi:10.1021/es703009q, 2008.

Bahreini, R., Dunlea, E. J., Matthew, B. M., Simons, C., Docherty, K. S., DeCarlo, P. F., Jimenez, J. L., Brock, C. A., and Middlebrook, A. M.: Design and operation of a pressure-controlled inlet for airborne sampling with an aerodynamic aerosol lens, Aerosol Sci. Tech., 42, 465-471, doi:10.1080/02786820802178514, 2008.

Bonasoni, P., Evangelisti, F., Bonafe, U., Ravegnani, F., Calzolari, F., Stohl, A., Tositti, L., Tubertini, O., and Colombo, T.: Stratospheric ozone intrusion episodes recorded at Mt. Cimone during the VOTALP project: case studies, Atmos. Environ., 34, 13551365, doi:10.1016/s1352-2310(99)00280-0, 2000.

Canagaratna, M., Jayne, J., Jimenez, J., Allan, J., Alfarra, M., Zhang, Q., Onasch, T., Drewnick, F., Coe, H., Middlebrook, A., Delia, A., Williams, L., Trimborn, A., Northway, M., DeCarlo, P., Kolb, C., Davidovits, P., and Worsnop, D.: Chemical and microphysical characterization of ambient aerosols with the aerodyne aerosol mass spectrometer, Mass Spectrom. Rev., 26, 185-222, doi:10.1002/mas.20115, 2007. 
Canagaratna, M. R., Jimenez, J. L., Kroll, J. H., Chen, Q., Kessler, S. H., Massoli, P., Hildebrandt Ruiz, L., Fortner, E., Williams, L. R., Wilson, K. R., Surratt, J. D., Donahue, N. M., Jayne, J. T., and Worsnop, D. R.: Elemental ratio measurements of organic compounds using aerosol mass spectrometry: characterization, improved calibration, and implications, Atmos. Chem. Phys., 15, 253-272, doi:10.5194/acp-15-253-2015, 2015.

Carbone, C., Decesari, S., Mircea, M., Giulianelli, L., Finessi, E., Rinaldi, M., Fuzzi, S., Marinoni, A., Duchi, R., Perrino, C., Sargolini, T., Varde, M., Sprovieri, F., Gobbi, G. P., Angelini, F., and Facchini, M. C.: Size-resolved aerosol chemical composition over the Italian Peninsula during typical summer and winter conditions, Atmos. Environ., 44, 5269-5278, doi:10.1016/j.atmosenv.2010.08.008, 2010.

Carbone, C., Decesari, S., Paglione, M., Giulianelli, L., Rinaldi, M., Marinoni, A., Cristofanelli, P., Didiodato, A., Bonasoni, P., Fuzzi, S., and Facchini, M. C.: 3-year chemical composition of free tropospheric $\mathrm{PM}_{1}$ at the Mt. Cimone GAW global station - South Europe - 2165 m a.s.1., Atmos. Environ., 87, 218-227, doi:10.1016/j.atmosenv.2014.01.048, 2014.

Chhabra, P. S., Ng, N. L., Canagaratna, M. R., Corrigan, A. L., Russell, L. M., Worsnop, D. R., Flagan, R. C., and Seinfeld, J. H.: Elemental composition and oxidation of chamber organic aerosol, Atmos. Chem. Phys., 11, 8827-8845, doi:10.5194/acp-11-88272011, 2011.

Collaud Coen, M., Weingartner, E., Furger, M., Nyeki, S., Prévôt, A. S. H., Steinbacher, M., and Baltensperger, U.: Aerosol climatology and planetary boundary influence at the Jungfraujoch analyzed by synoptic weather types, Atmos. Chem. Phys., 11, 5931-5944, doi:10.5194/acp-11-5931-2011, 2011.

Crippa, M., El Haddad, I., Slowik, J. G., DeCarlo, P. F., Mohr, C., Heringa, M. F., Chirico, R., Marchand, N., Sciare,J., Baltensperger, U., and Prévôt, A. S. H.: Identification of marine and continental aerosol sources in Paris using high resolution aerosol mass spectrometry, J. Geophys. Res.-Atmos., 118, 1950-1963, doi:10.1002/jgrd.50151, 2013

Cristofanelli, P., Bonasoni, P., Carboni, G., Calzolari, F., Casarola, L., Sajani, S. Z., and Santaguida, R.: Anomalous high ozone concentrations recorded at a high mountain station in Italy in summer 2003, Atmos. Environ., 41, 1383-1394, doi:10.1016/j.atmosenv.2006.10.017, 2007.

Cristofanelli, P., Scheel, H. E., Steinbacher, M., Saliba, M., Azzopardi, F., Ellul, R., Froehlich, M., Tositti, L., Brattich, E., Maione, M., Calzolari, F., Duchi, R., Landi, T. C., Marinoni, A., and Bonasoni, P.: Long-term surface ozone variability at Mt. Cimone WMO/GAW global station (2165 m a.s.l., Italy), Atmos. Environ., 101, 23-33, doi:10.1016/j.atmosenv.2014.11.012, 2015.

Cubison, M. J., Ortega, A. M., Hayes, P. L., Farmer, D. K., Day, D., Lechner, M. J., Brune, W. H., Apel, E., Diskin, G. S., Fisher, J. A., Fuelberg, H. E., Hecobian, A., Knapp, D. J., Mikoviny, T., Riemer, D., Sachse, G. W., Sessions, W., Weber, R. J., Weinheimer, A. J., Wisthaler, A., and Jimenez, J. L.: Effects of aging on organic aerosol from open biomass burning smoke in aircraft and laboratory studies, Atmos. Chem. Phys., 11, 12049-12064, doi:10.5194/acp-11-12049-2011, 2011.

DeCarlo, P., Kimmel, J., Trimborn, A., Northway, M., Jayne, J., Aiken, A., Gonin, M., Fuhrer, K., Horvath, T., Docherty, K., Worsnop, D., and Jimenez, J.: Field-deployable, high-resolution, time-of-flight aerosol mass spectrometer, Anal. Chem., 78, 8281-8289, doi:10.1021/ac061249n, 2006.

DeCarlo, P. F., Dunlea, E. J., Kimmel, J. R., Aiken, A. C., Sueper, D., Crounse, J., Wennberg, P. O., Emmons, L., Shinozuka, Y., Clarke, A., Zhou, J., Tomlinson, J., Collins, D. R., Knapp, D., Weinheimer, A. J., Montzka, D. D., Campos, T., and Jimenez, J. L.: Fast airborne aerosol size and chemistry measurements above Mexico City and Central Mexico during the MILAGRO campaign, Atmos. Chem. Phys., 8, 4027-4048, doi:10.5194/acp-84027-2008, 2008.

Decesari, S., Facchini, M. C., Fuzzi, S., Mentel, T., Ganzeveld, L., Nemitz, E., Bonafé, G., Morgillo, A., Poluzzi, V., and Pandis, S.: The 2012 PEGASOS-SUPERSITO Po Valley campaign: an overview, in preparation, 2015.

Duplissy, J., DeCarlo, P. F., Dommen, J., Alfarra, M. R., Metzger, A., Barmpadimos, I., Prevot, A. S. H., Weingartner, E., Tritscher, T., Gysel, M., Aiken, A. C., Jimenez, J. L., Canagaratna, M. R., Worsnop, D. R., Collins, D. R., Tomlinson, J., and Baltensperger, U.: Relating hygroscopicity and composition of organic aerosol particulate matter, Atmos. Chem. Phys., 11, 11551165, doi:10.5194/acp-11-1155-2011, 2011.

Fischer, H., Kormann, R., Klüpfel, T., Gurk, Ch., Königstedt, R., Parchatka, U., Mühle, J., Rhee, T. S., Brenninkmeijer, C. A. M., Bonasoni, P., and Stohl, A.: Ozone production and trace gas correlations during the June 2000 MINATROC intensive measurement campaign at Mt. Cimone, Atmos. Chem. Phys., 3, 725-738, doi:10.5194/acp-3-725-2003, 2003.

Freney, E. J., Sellegri, K., Canonaco, F., Boulon, J., Hervo, M., Weigel, R., Pichon, J. M., Colomb, A., Prévôt, A. S. H., and Laj, P.: Seasonal variations in aerosol particle composition at the puy-de-Dôme research station in France, Atmos. Chem. Phys., 11, 13047-13059, doi:10.5194/acp-11-13047-2011, 2011.

Gilardoni, S., Liu, S., Takahama, S., Russell, L. M., Allan, J. D., Steinbrecher, R., Jimenez, J. L., De Carlo, P. F., Dunlea, E. J., and Baumgardner, D.: Characterization of organic ambient aerosol during MIRAGE 2006 on three platforms, Atmos. Chem. Phys., 9, 5417-5432, doi:10.5194/acp-9-5417-2009, 2009.

Gilardoni, S., Massoli, P., Giulianelli, L., Rinaldi, M., Paglione, M., Pollini, F., Lanconelli, C., Poluzzi, V., Carbone, S., Hillamo, R., Russell, L. M., Facchini, M. C., and Fuzzi, S.: Fog scavenging of organic and inorganic aerosol in the Po Valley, Atmos. Chem. Phys., 14, 6967-6981, doi:10.5194/acp-14-6967-2014, 2014.

Hayes, P. L., Ortega, A. M., Cubison, M. J., Froyd, K. D., Zhao, Y., Cliff, S. S., Hu, W. W., Toohey, D. W., Flynn, J. H., Lefer, B. L., Grossberg, N., Alvarez, S., Rappenglueck, B., Taylor, J. W., Allan, J. D., Holloway, J. S., Gilman, J. B., Kuster, W. C., De Gouw, J. A., Massoli, P., Zhang, X., Liu, J., Weber, R. J., Corrigan, A. L., Russell, L. M., Isaacman, G., Worton, D. R., Kreisberg, N. M., Goldstein, A. H., Thalman, R., Waxman, E. M., Volkamer, R., Lin, Y. H., Surratt, J. D., Kleindienst, T. E., Offenberg, J. H., Dusanter, S., Griffith, S., Stevens, P. S., Brioude, J., Angevine, W. M., and Jimenez, J. L.: Organic aerosol composition and sources in Pasadena, California, during the 2010 CalNex campaign, J. Geophys. Res.-Atmos., 118, 9233-9257, doi:10.1002/jgrd.50530, 2013.

Heald, C. L., Kroll, J. H., Jimenez, J. L., Docherty, K. S., DeCarlo, P. F., Aiken, A. C., Chen, Q., Martin, S. T., Farmer, D. K., and Artaxo, P.: A simplified description of the evolution of organic 
aerosol composition in the atmosphere, Geophys. Res. Lett., 37, L08803, doi:10.1029/2010g1042737, 2010.

Henne, S., Furger, M., and Prevot, A. S. H.: Climatology of mountain venting-induced elevated moisture layers in the lee of the Alps, J. Appl. Meteorol., 44, 620-633, doi:10.1175/jam2217.1, 2005.

Henne, S., Klausen, J., Junkermann, W., Kariuki, J. M., Aseyo, J. O., and Buchmann, B.: Representativeness and climatology of carbon monoxide and ozone at the global GAW station Mt. Kenya in equatorial Africa, Atmos. Chem. Phys., 8, 31193139, doi:10.5194/acp-8-3119-2008, 2008.

Hildebrandt, L., Kostenidou, E., Mihalopoulos, N., Worsnop, D., Donahue, N., and Pandis, S.: Formation of highly oxygenated organic aerosol in the atmosphere: Insights from the Finokalia aerosol measurement experiments, Geophys. Res. Lett., 37, L23801, doi:10.1029/2010g1045193, 2010.

Hock, N., Schneider, J., Borrmann, S., Römpp, A., Moortgat, G., Franze, T., Schauer, C., Pöschl, U., Plass-Dülmer, C., and Berresheim, H.: Rural continental aerosol properties and processes observed during the Hohenpeissenberg Aerosol Characterization Experiment (HAZE2002), Atmos. Chem. Phys., 8, 603-623, doi:10.5194/acp-8-603-2008, 2008.

Holzinger, R., Goldstein, A. H., Hayes, P. L., Jimenez, J. L., and Timkovsky, J.: Chemical evolution of organic aerosol in Los Angeles during the CalNex 2010 study, Atmos. Chem. Phys., 13, 10125-10141, doi:10.5194/acp-13-10125-2013, 2013.

Jayne, J., Leard, D., Zhang, X., Davidovits, P., Smith, K., Kolb, C., and Worsnop, D.: Development of an aerosol mass spectrometer for size and composition analysis of submicron particles, Aerosol Sci. Tech., 33, 49-70, doi:10.1080/027868200410840, 2000.

Jimenez, J., Canagaratna, M., Donahue, N., Prevot, A., Zhang, Q., Kroll, J., DeCarlo, P., Allan, J., Coe, H., Ng, N., Aiken, A., Docherty, K., Ulbrich, I., Grieshop, A., Robinson, A., Duplissy, J., Smith, J., Wilson, K., Lanz, V., Hueglin, C., Sun, Y., Tian, J., Laaksonen, A., Raatikainen, T., Rautiainen, J., Vaattovaara, P., Ehn, M., Kulmala, M., Tomlinson, J., Collins, D., Cubison, M., Dunlea, E., Huffman, J., Onasch, T., Alfarra, M., Williams, P., Bower, K., Kondo, Y., Schneider, J., Drewnick, F., Borrmann, S., Weimer, S., Demerjian, K., Salcedo, D., Cottrell, L., Griffin, R., Takami, A., Miyoshi, T., Hatakeyama, S., Shimono, A., Sun, J., Zhang, Y., Dzepina, K., Kimmel, J., Sueper, D., Jayne, J., Herndon, S., Trimborn, A., Williams, L., Wood, E., Middlebrook, A., Kolb, C., Baltensperger, U., and Worsnop, D.: Evolution of organic aerosols in the atmosphere, Science, 326, 15251529, doi:10.1126/science.1180353, 2009.

Jimenez, J. L., Jayne, J. T., Shi, Q., Kolb, C. E., Worsnop, D. R., Yourshaw, I., Seinfeld, J. H., Flagan, R. C., Zhang, X. F., Smith, K. A., Morris, J. W., and Davidovits, P.: Ambient aerosol sampling using the Aerodyne aerosol mass spectrometer, J. Geophys. Res.-Atmos., 108, 8425, doi:10.1029/2001jd001213, 2003.

Kroll, J., Smith, J., Che, D., Kessler, S., Worsnop, D., and Wilson, K.: Measurement of fragmentation and functionalization pathways in the heterogeneous oxidation of oxidized organic aerosol, Phys. Chem. Chem. Phys., 11, 8005-8014, doi:10.1039/b905289e, 2009.

Kroll, J., Donahue, N., Jimenez, J., Kessler, S., Canagaratna, M., Wilson, K., Altieri, K., Mazzoleni, L., Wozniak, A., Bluhm, H., Mysak, E., Smith, J., Kolb, C., and Worsnop, D.: Carbon oxidation state as a metric for describing the chemistry of atmospheric organic aerosol, Nature Chemistry, 3, 133-139, doi:10.1038/nchem.948, 2011.

Lambe, A. T., Ahern, A. T., Williams, L. R., Slowik, J. G., Wong, J. P. S., Abbatt, J. P. D., Brune, W. H., Ng, N. L., Wright, J. P., Croasdale, D. R., Worsnop, D. R., Davidovits, P., and Onasch, T. B.: Characterization of aerosol photooxidation flow reactors: heterogeneous oxidation, secondary organic aerosol formation and cloud condensation nuclei activity measurements, Atmos. Meas. Tech., 4, 445-461, doi:10.5194/amt-4-445-2011, 2011.

Lanz, V., Alfarra, M., Baltensperger, U., Buchmann, B., Hueglin, C., Szidat, S., Wehrli, M., Wacker, L., Weimer, S., Caseiro, A., Puxbaum, H., and Prevot, A.: Source attribution of submicron organic aerosols during wintertime inversions by advanced factor analysis of aerosol mass spectra, Environ. Sci. Technol., 42, 214 220, doi:10.1021/es0707207, 2008

Lanz, V. A., Prévôt, A. S. H., Alfarra, M. R., Weimer, S., Mohr, C., DeCarlo, P. F., Gianini, M. F. D., Hueglin, C., Schneider, J., Favez, O., D'Anna, B., George, C., and Baltensperger, U.: Characterization of aerosol chemical composition with aerosol mass spectrometry in Central Europe: an overview, Atmos. Chem. Phys., 10, 10453-10471, doi:10.5194/acp-10-10453-2010, 2010.

Liu, P. S. K., Deng, R., Smith, K. A., Williams, L. R., Jayne, J. T., Canagaratna, M. R., Moore, K., Onasch, T. B., Worsnop, D. R., and Deshler, T.: Transmission efficiency of an aerodynamic focusing lens system: Comparison of model calculations and laboratory measurements for the Aerodyne Aerosol Mass Spectrometer, Aerosol Sci. Tech., 41, 721-733, doi:10.1080/02786820701422278, 2007.

Marenco, F., Bonasoni, P., Calzolari, F., Ceriani, M., Chiari, M., Cristofanelli, P., D'Alessandro, A., Fermo, P., Lucarelli, F., Mazzei, F., Nava, S., Piazzalunga, A., Prati, P., Valli, G., and Vecchi, R.: Characterization of atmospheric aerosols at Monte Cimone, Italy, during summer 2004: Source apportionment and transport mechanisms, J. Geophys. Res.-Atmos., 111, D24202, doi:10.1029/2006jd007145, 2006.

Marinoni, A., Cristofanelli, P., Calzolari, F., Roccato, F., Bonafe, U., and Bonasoni, P.: Continuous measurements of aerosol physical parameters at the Mt. Cimone GAW Station (2165 masl, Italy), Sci. Total Environ., 391, 241-251, doi:10.1016/j.scitotenv.2007.10.004, 2008.

Massoli, P., Lambe, A. T., Ahern, A. T., Williams, L. R., Ehn, M., Mikkila, J., Canagaratna, M. R., Brune, W. H., Onasch, T. B., Jayne, J. T., Petaja, T., Kulmala, M., Laaksonen, A., Kolb, C. E., Davidovits, P., and Worsnop, D. R.: Relationship between aerosol oxidation level and hygroscopic properties of laboratory generated secondary organic aerosol (SOA) particles, Geophys. Res. Lett., 37, L24801, doi:10.1029/2010g1045258, 2010.

Middlebrook, A. M., Bahreini, R., Jimenez, J. L., and Canagaratna, M. R.: Evaluation of composition-dependent collection efficiencies for the Aerodyne aerosol mass spectrometer using field data, Aerosol Sci. Tech., 46, 258-271, doi:10.1080/02786826.2011.620041, 2012.

Mohr, C., DeCarlo, P. F., Heringa, M. F., Chirico, R., Slowik, J. G., Richter, R., Reche, C., Alastuey, A., Querol, X., Seco, R., Peñuelas, J., Jiménez, J. L., Crippa, M., Zimmermann, R., Baltensperger, U., and Prévôt, A. S. H.: Identification and quantification of organic aerosol from cooking and other sources in Barcelona using aerosol mass spectrometer data, Atmos. Chem. Phys., 12, 1649-1665, doi:10.5194/acp-12-1649-2012, 2012. 
Morgan, W. T., Allan, J. D., Bower, K. N., Highwood, E. J., Liu, D., McMeeking, G. R., Northway, M. J., Williams, P. I., Krejci, R., and Coe, H.: Airborne measurements of the spatial distribution of aerosol chemical composition across Europe and evolution of the organic fraction, Atmos. Chem. Phys., 10, 4065-4083, doi:10.5194/acp-10-4065-2010, 2010.

Ng, N. L., Canagaratna, M. R., Zhang, Q., Jimenez, J. L., Tian, J., Ulbrich, I. M., Kroll, J. H., Docherty, K. S., Chhabra, P. S., Bahreini, R., Murphy, S. M., Seinfeld, J. H., Hildebrandt, L., Donahue, N. M., DeCarlo, P. F., Lanz, V. A., Prévôt, A. S. H., Dinar, E., Rudich, Y., and Worsnop, D. R.: Organic aerosol components observed in Northern Hemispheric datasets from Aerosol Mass Spectrometry, Atmos. Chem. Phys., 10, 46254641, doi:10.5194/acp-10-4625-2010, 2010.

Ng, N. L., Canagaratna, M. R., Jimenez, J. L., Chhabra, P. S., Seinfeld, J. H., and Worsnop, D. R.: Changes in organic aerosol composition with aging inferred from aerosol mass spectra, Atmos. Chem. Phys., 11, 6465-6474, doi:10.5194/acp-11-64652011, 2011.

Paatero, P. and Tapper, U.: Positive matrix factorization a nonnegative factor model with optimal utilization of error-estimates of data values, Environmetrics, 5, 111-126, doi:10.1002/env.3170050203, 1994.

Pang, Y., Turpin, B. J., and Gundel, L. A.: On the importance of organic oxygen for understanding organic aerosol particles, Aerosol Sci. Tech., 40, 128-133, doi:10.1080/02786820500423790, 2006.

Petzold, A., Kramer, H., and Schonlinner, M.: Continuous measurement of atmospheric black carbon using a multi-angle absorption photometer, Environ. Sci. Pollut. R., 4, 78-82, 2002.

Prévôt, A. S. H., Dommen, J., and Baumle, M.: Influence of road traffic on volatile organic compound concentrations in and above a deep Alpine valley, Atmos. Environ., 34, 4719-4726, doi:10.1016/s1352-2310(00)00254-5, 2000.

Putaud, J.-P., Van Dingenen, R., Dell'Acqua, A., Raes, F., Matta, E., Decesari, S., Facchini, M. C., and Fuzzi, S.: Size-segregated aerosol mass closure and chemical composition in Monte Cimone (I) during MINATROC, Atmos. Chem. Phys., 4, 889-902, doi:10.5194/acp-4-889-2004, 2004.

Saarikoski, S., Carbone, S., Decesari, S., Giulianelli, L., Angelini, F., Canagaratna, M., Ng, N. L., Trimborn, A., Facchini, M. C., Fuzzi, S., Hillamo, R., and Worsnop, D.: Chemical characterization of springtime submicrometer aerosol in Po Valley, Italy, Atmos. Chem. Phys., 12, 8401-8421, doi:10.5194/acp-12-84012012, 2012.

Schuepbach, E., Friedli, T. K., Zanis, P., Monks, P. S., and Penkett, S. A.: State space analysis of changing seasonal ozone cycles (1988-1997) at Jungfraujoch (3580 m above sea level) in Switzerland, J. Geophys. Res.-Atmos., 106, 20413-20427, doi:10.1029/2000jd900591, 2001.

Seinfeld, J. H. and Pankow, J. F.: Organic atmospheric particulate material, Annu. Rev. Phys. Chem., 54, 121-140, doi:10.1146/annurev.physchem.54.011002.103756, 2003.
Steinbacher, M., Zellweger, C., Schwarzenbach, B., Bugmann, S., Buchmann, B., Ordonez, C., Prevot, A. S. H., and Hueglin, C.: Nitrogen oxide measurements at rural sites in Switzerland: Bias of conventional measurement techniques, J. Geophys. Res.Atmos., 112, D11307, doi:10.1029/2006jd007971, 2007.

Sun, Y., Zhang, Q., Macdonald, A. M., Hayden, K., Li, S. M., Liggio, J., Liu, P. S. K., Anlauf, K. G., Leaitch, W. R., Steffen, A., Cubison, M., Worsnop, D. R., van Donkelaar, A., and Martin, R. V.: Size-resolved aerosol chemistry on Whistler Mountain, Canada with a high-resolution aerosol mass spectrometer during INTEX-B, Atmos. Chem. Phys., 9, 3095-3111, doi:10.5194/acp9-3095-2009, 2009.

Sun, Y.-L., Zhang, Q., Schwab, J. J., Demerjian, K. L., Chen, W.N., Bae, M.-S., Hung, H.-M., Hogrefe, O., Frank, B., Rattigan, O. V., and Lin, Y.-C.: Characterization of the sources and processes of organic and inorganic aerosols in New York city with a high-resolution time-of-flight aerosol mass apectrometer, Atmos. Chem. Phys., 11, 1581-1602, doi:10.5194/acp-11-15812011, 2011a.

Sun, Y. L., Zhang, Q., Schwab, J. J., Chen, W. N., Bae, M. S., Lin, Y. C., Hung, H. M., and Demerjian, K. L.: A case study of aerosol processing and evolution in summer in New York City, Atmos. Chem. Phys., 11, 12737-12750, doi:10.5194/acp11-12737-2011, $2011 \mathrm{~b}$.

Takegawa, N., Miyakawa, T., Kawamura, K., and Kondo, Y.: Contribution of selected dicarboxylic and omega-oxocarboxylic acids in ambient aerosol to the $m / z, 44$ signal of an aerodyne aerosol mass spectrometer, Aerosol Sci. Tech., 41, 418-437, doi:10.1080/02786820701203215, 2007.

Ulbrich, I. M., Canagaratna, M. R., Zhang, Q., Worsnop, D. R., and Jimenez, J. L.: Interpretation of organic components from Positive Matrix Factorization of aerosol mass spectrometric data, Atmos. Chem. Phys., 9, 2891-2918, doi:10.5194/acp-9-2891-2009, 2009.

Van Krevelen, D. W.: Graphical-statistical method for the study of structure and reaction processes of coal, Fuel, 24, 269-284, 1950.

Zhang, Q., Jimenez, J., Canagaratna, M., Allan, J., Coe, H., Ulbrich, I., Alfarra, M., Takami, A., Middlebrook, A., Sun, Y., Dzepina, K., Dunlea, E., Docherty, K., DeCarlo, P., Salcedo, D., Onasch, T., Jayne, J., Miyoshi, T., Shimono, A., Hatakeyama, S., Takegawa, N., Kondo, Y., Schneider, J., Drewnick, F., Borrmann, S., Weimer, S., Demerjian, K., Williams, P., Bower, K., Bahreini, R., Cottrell, L., Griffin, R., Rautiainen, J., Sun, J., Zhang, Y., and Worsnop, D.: Ubiquity and dominance of oxygenated species in organic aerosols in anthropogenicallyinfluenced Northern Hemisphere midlatitudes, Geophys. Res. Lett., 34, L13801, doi:10.1029/2007g1029979, 2007.

Zhang, Q., Jimenez, J., Canagaratna, M., Ulbrich, I., Ng, N., Worsnop, D., and Sun, Y.: Understanding atmospheric organic aerosols via factor analysis of aerosol mass spectrometry: a review, Anal. Bioanal. Chem., 401, 3045-3067, doi:10.1007/s00216-011-5355-y, 2011. 